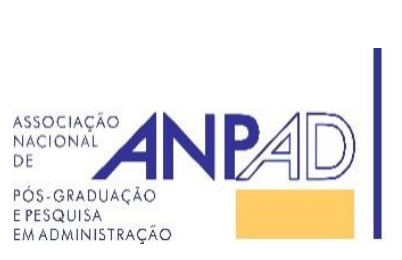

Available online at http://www.anpad.org.br/bar

BAR, Rio de Janeiro, v. 14, n. 1, art. 1, e160091, 2017

\title{
Ethical Decision-Making: The Role of Self-Monitoring, Future Orientation, and Social Networks
}

Ana Carla Bon ${ }^{1}$ Roger James Volkema ${ }^{1}$ Jorge Ferreira da Silva ${ }^{1}$

Pontifícia Universidade Católica do Rio de Janeiro ${ }^{1}$

Received 16 September 2016; received in revised form in 11 December 2016; accepted in 19 December 2016; first published online 23 February 2017.

Editor's note. Maria Luisa Mendes Teixeira served as Action Editor for this article. 


\begin{abstract}
This study examines the influence of individual factors (self-monitoring, temporal orientation) on social networking, and their relationship with unethical decision-making. The study used surveys to measure the unethical intentions and social network data of 129 professionals. Data were analyzed using confirmatory factor analysis and structural equation modeling. The findings provided evidence that individual factors influence the development of social networks and, along with self-monitoring, the likelihood of unethical decision-making. In particular, being in positions of lower network centrality increased individuals' risk of unethical intention. One explanation stems from the need for high situation control to reduce risk and ensure the success of an event, which only a closed network can provide. However, ethical low self-monitor women were also found to have low centrality, so social networks alone do not explain ethical decision-making. This research represents a step forward in our understanding of ethical decision-making through the adoption of multiple and simultaneous factors, proposing an integrated theory of individual and situational factors influencing unethical options.
\end{abstract}

Key words: ethical decision-making; future orientation; self-monitoring; social networks. 


\section{Introduction}

Over the past several decades, fraud and corruption have received increasing attention worldwide by both policymakers and academics. This attention has been due in part to the surfeit of high-profile cases reported in the popular press (e.g., Enron, WorldCom, Parmalat, Siemens, Petrobras) as well as the vast sums of money involved. According to Garrett (2014), since 2001 there have been more than 250 federal prosecutions in the United States alone involving large corporations worldwide. The twenty largest fines from 2001-2012 totaled US\$8.9 billion and involved companies such as Siemens, Kellogg Brown \& Root and BAE (corruption), LG Display and Air France/KLM (antitrust), Pharmacia \& Upjohn and GlaxoSmithKline (pharmaceutical related crimes), and UBS (fraud).

As attitudes and values regarding unethical behavior are not formed in isolation (Gunia, Wang, Huang, Wang, \& Murnighan, 2012; Martin, Cullen, Johnson, \& Parboteeah, 2007) and corruption typically involves the complicity of other parties (Ayios, Jeurissen, Manning, \& Spence, 2014; Brass, Butterfield, \& Skaggs, 1998; Nielsen, 2003), a key element in understanding the emergence and perpetuation of corruption is relational networks. The currency of network development is social capital, which constitutes an investment in social relations with expected returns (Lin, 2001). The network of relationships that results from these investment strategies can be used by an individual in the short or long term to access other actors' resources. Thus, business relationships are transformed into a marketplace of contacts to ensure competitive advantage, often by means that include fraud and corruption (Collins, Uhlenbruck, \& Rodriguez, 2009). Therefore, to understand and manage unethical behavior within and between organizations, it is necessary to focus on individuals' networks.

Recognizing the importance of networking structures in organizational decision-making, including their likely role in affecting unethical decisions and behavior, a number of researchers have sought to investigate these linkages using varied methodologies. With respect to unethical decisionmaking, however, the findings to date have been inconclusive. Distinct and mutually exclusive network structures have been suggested to increase the risk of unethical decision-making (e.g., Bizzi, 2013; Brass et al., 1998; Flynn \& Wiltermuth, 2010; Lee, 2013).

There are other variables, however, that could affect the development of social capital and explain the inconsistencies regarding the influence networks have on decision-making, including individual factors related to social awareness, motivation, and persistence (Hershfield, Cohen, \& Thompson, 2012; Holman \& Zimbardo, 2009; H. Oh \& Kilduff, 2008). According to Payne, Moore, Griffis, and Autry (2011), who reviewed two decades of social capital research within the context of organizations (19892008), there has been a scarcity of studies analyzing the antecedents of social capital. Personality characteristics, in particular, which could play a direct role in this developmental process (as certain personalities are more adroit than others in raising and managing social capital), have been largely overlooked (Mehra, Kilduff, \& Brass, 2001). An examination of moderating effects could also provide some answers to the inconsistencies in research findings concerning the role of social structures in unethical decision-making, as some personality types are likely to be more effective than other types in exploiting certain network structures.

This paper reports on a study of social networks, a fundamental contextual factor in understanding ethics in organizational decision-making. Beyond the application of multiple predictors, this study examines how individual factors can influence the creation of social networks, and how the linking of these factors can reveal the dark side of business decision-making. We analyzed the ethical decisionmaking of 129 professionals from across hierarchical levels. As the development of social networks requires select interpersonal skills applied over time, the study includes two personality measures: selfmonitoring (Gangestad \& Snyder, 2000; Snyder, 1987) - one's ability to perceive social cues and adapt behaviors to impress others - and temporal perspective (Zimbardo \& Boyd, 1999). The results of the analyses offer a better understanding of the potential antecedents of social networking and the relationship of individual and situational factors with respect to ethical decision-making, results that have implications for policymakers and future research. 


\section{Theoretical Background and Hypotheses}

Craft (2013) noted that the two models most often employed in ethical decision-making research are Rest's (1986) model for Individual Ethical Decision-making (based on a four-step model of awareness, judgment, intention and behavior of a moral issue) and Jones' (1991) Issue-Contingent Model. Jones' model is a synthesis of previous models, such as the person-situation interactionist model defined by Trevino (1986), and uses Rest's model as its basis. Jones also assumed that actual behavior is a function of behavioral intentions, based on the Theory of Reasoned Action (Ajzen \& Fishbein, 1980). In addition, Jones (1991) developed the concept of moral intensity - based on social cognition theories - arguing that ethical decision-making is issue contingent (i.e., the characteristics of the moral issue are determinants of ethical decision-making and behavior).

Kish-Gephart, Harrison, and Trevino (2010) define unethical intentions as the expression of one's willingness or commitment to engage in an unethical behavior and, within an organizational context, unethical behavior as any organizational member's action that violates generally-accepted societal moral norms. As these definitions suggest, ethics at its core is a social construct. Nonetheless, much of the research to date has focused on the relationship of demographic and personality factors to unethical decision-making rather than understanding the social networks that underpin this decisional process (for reviews, see: Craft, 2013; Ford \& Richardson, 1994; Loe, Ferrel, \& Mansfield, 2000; O'Fallon \& Butterfield, 2005).

Ajzen's theories of reasoned action (Ajzen \& Fishbein, 1980) and planned behavior (Ajzen, 1991) offer frameworks for understanding the role of social networks and social capital in this cognitive process. According to the theory of planned behavior, intention and perceived behavioral control (abilities) combine to explain behavior. As such, intentions are influenced by attitudes (the degree to which an individual has a positive evaluation of the behavior), subjective norms (an individual's belief about what significant others think he or she should do), and perceived behavioral control (the perceived ease of performing the behavior based on experience or anticipated problems). Ajzen argued that while intentions explain the motivational factors that influence an individual's behavior, to really perform an action the actor depends on other non-motivational factors, such as time, economic resources, or the cooperation of others. Azjen also observed that beliefs (salient information) are antecedents that predict intentions. Therefore, the antecedents of subjective norms are normative antecedents, that is, requiring approval or disapproval of performing a given behavior by an important referent (individual or group).

The importance of a referent group was noted as well by Jones and Ryan (1997) in their extension of Jones' (1991) model, which included the concept of moral approbation in organizations (i.e., moral approval from oneself or others). The concept of moral approbation posits that individuals will only decide on a moral intention if they feel comfortable with a certain threshold of approval of their behavior. Jones and Ryan (1997) argued that an individual may feel pressure to comply with organizational directives (not necessarily direction to behave unethically, but pressure to achieve some results) and that the degree of complicity is difficult to prove insofar as it is common to find decisions dispersed among several people or units within a firm. They also argued that there are differences at the individual level in the approbation model, as approbation can vary both in the individual need for approval (which can include self-attribution of responsibility) and in the size and composition of a referent group (which can lead to possible bias by individuals with large or poorly understood referent groups).

There are many significant others that can influence an individual's ethical decision-making within an organization and provide the means for effecting an unethical act, including top management, direct managers/supervisors, peers inside the company, and even other managers in the same industry or market (Craft, 2013). It is generally the case that organizational structure defines an actor's peers; however, there are individual factors that influence the definition of who, among peers, are the significant referents. That is, actors in a firm maintain relationships, building their own social networks, which in turn provide social identity (Ibarra, Kilduff, \& Tsai, 2005). Actors in a social network are social referents to each other, at the same time that social identity affects networks. 
Seeking to differentiate among the social referents in an organizational context, Shah (1998) discovered that for job-related information, employees often rely on other structural equivalents, but for general information (e.g., social comparisons) employees will use their cohesive ties. The strong-ties theory says that a closed network (the extent to which an individual's contacts are themselves connected) is important for the emergence of norms and trust (Coleman, 1990). Where an individual's contacts are not themselves linked, the violation of norms is more likely to go undetected and unpunished (Adler \& Kwon, 2002). As norms are clear and enforced in networks where everyone is connected, there is less opportunism and consequently less need for costly monitoring of members (Coleman, 1990). That is, individuals in closed networks know who the significant others are and what their values are.

Consistent with Jones and Ryan's (1997) discussion of approbation bias, Flynn and Wiltermuth (2010) found that brokers - individuals who span structural holes (Burt, 1992) - often have a false consensus bias (i.e., they overestimate the degree to which other organization members share their views on ethical matters), presenting a higher risk of unethical acts. This includes brokers being associated with unethical acts against their group as well as others (Bizzi, 2013). Arguably, this is due to their high network centrality (i.e., they connect individuals who are not connected among themselves) and therefore norms are not very salient among them. With respect to an individual's centrality within a social network, therefore, we would expect the following:

H1: The higher an individual's brokerage (centrality) in his/her advice social network, the more likely he/she will have unethical intentions.

Although individual factors such as personality have been studied regarding their relation to ethical decision-making (Craft, 2013; Ford \& Richardson, 1994; O'Fallon \& Butterfield, 2005), their role in fostering the development of social networks has been largely overlooked, despite the importance of understanding the process by which individuals choose social situations. Snyder and Kendzierski (1982) argued the importance of understanding this expanded paradigm, as it could provide "a basis for conceptualizing and investigating the mutual interplay and reciprocal influences of individuals and social situations - by their choices of social situations, individuals may determine the social situation that in turn may determine their own behavior" (p. 293).

Drawing on Ajzen's (1991) Theory of Planned Behavior and Jones and Ryan's (1997) extension of the Issue-Contingent Model, the development of the social capital/networks necessary to engage in illicit behavior depends on both motivational (attitude, personality) and non-motivational (time, economic resources) factors. Not everyone is fit for cultivating social relationships, let alone relations that someday might serve the purpose of promoting one's illicit self-interests. While there are potentially many personality characteristics that could influence the creation and maintenance of social networks (Dougherty, Cheung, \& Florea, 2008), there are two expected to meet the requirements for affecting both network development and unethical decision-making: self-monitoring and future orientation.

Self-monitoring is a personality trait which is particularly relevant to understanding how identity and impression management skills influence an individual's network structure. Self-monitoring theory makes clear predictions concerning the effects self-monitors have in shaping their social worlds (Mehra et al., 2001; Sasovova, Mehra, Borgatti, \& Schippers, 2010; Snyder, 1987).

The theory of self-monitoring contends that "people differ in the extent to which they can and do engage in expressive control", i.e., the extent to which they "value, create, cultivate and project social images and public appearances" (Gangestad \& Snyder, 2000, pp. 530-531). High self-monitors have the "ability to perceive social cues and adapt their behavior to impress others, while low self-monitors do not adapt to the situation, instead reflecting their own inner attitudes, emotions, and dispositions" (Gangestad \& Snyder, 2000, p. 531).

Further, people develop their social worlds through the "use of strategic activities that support and perpetuate their self-monitoring propensities" (Snyder, 1987, p. 58). High self-monitors cultivate public images of social status and, therefore, construct social worlds that can function as instruments of status enhancement, whereas low self-monitors construct social networks that support their reputations 
as "genuine and sincere people" (Gangestad \& Snyder, 2000, p. 547). As Snyder (1987, p. 58) explains, "it is low self-monitors for whom issues of 'character', and high self-monitors for whom matters of 'activities' are paramount when contracting and maintaining friendships".

Therefore, high self-monitors appear to be better than low self-monitors at maintaining relationships with different types of people and see no need to join these different types of people with each other (H. Oh \& Kilduff, 2008). That is, we might expect them to seek positions as brokers in high centrality networks. Indeed, the self-monitoring literature has generally reported high self-monitors to be positively associated with more central/brokerage positions in their social networks (e.g., Mehra et al., 2001; H. Oh \& Kilduff, 2008; Sasovova et al., 2010), although other studies (Janicki \& Larrick, 2005; Kalish \& Robins, 2006) did not present consistent results tying high self-monitors to social structures.

Low self-monitors, on the other hand, invest more in close relationships, where partners can be trusted (Gangestad \& Snyder, 2000). They prefer a homogeneous world of friendship (Snyder, Gangestad, \& Simpson, 1983), have a less compartmentalized social world than do high self-monitors (who tend to prefer different partners for different activities), and are inclined to form more highly committed relationships (Snyder \& Simpson, 1984). Therefore, with respect to social networking, we would expect that:

H2: The higher an individual's self-monitoring, the more likely he/she will exhibit brokerage (centrality) in his/her advice social network.

Regarding ethicality, high self-monitors are sometimes seen as the chameleons of the social world (Gangestad \& Snyder, 2000). Because they are concerned with social networks as a means to status enhancement, they can be more susceptible to unethical influences (Day \& Schleicher, 2006) and a corrupt environment (Pinto, Leana, \& Pil, 2008). In contrast, low self-monitors are careful about their reputations of sincerity (Gangestad \& Snyder, 2000). They are more comfortable with ambiguity (Day, Schleicher, Unckless, \& Hiller, 2002), such as ethical dilemmas that are inherently ambiguous (Day \& Schleicher, 2006), and suffer less from the pressures of others (Kilduff, 1992).

Day and Schleicher (2006, p. 700) argued that "high self-monitors will look to others for clues regarding ethical dilemmas, but low self-monitors will rely on their internalized values". Therefore, if ethical behavior is the prevailing norm, high self-monitors would tend to follow the norms, but they can also be more susceptible to unethical influences in order to adapt their behavior to others.

The question then is how people determine the prevailing norm (i.e., not the norm at the societal level, but the norm of their referent group). As the Theory of Reasoned Action proposes (Ajzen \& Fishbein, 1980), individual intentions are influenced by subjective norms, that is, by an individual's belief about what significant others think he or she should do. Since we have proposed (Hypothesis 2) that high self-monitors will be associated with high centrality networks (i.e., serving as brokers in networks where few others are connected), we would expect that norms would be less salient for them. On the other hand, low self-monitors would follow the norms of their socially homogeneous and consistent group, and care about their reputation of sincerity.

Although there can be exceptions, as the case where low self-monitors build closed, unethical networks, we are inclined to believe that high self-monitors are more likely to lean towards unethical decision-making. In fact, high self-monitors are likely to engage in OCBs (organizational citizenship behavior) for questionable motives (Bolino, Klotz, Turnley, \& Harvey, 2013), use bogus personal information to get a job (Hogue, Levashina, \& Hang, 2013) and employ impression management tactics to create false representations of embracing company values (Hewlin, 2003). They are also more likely, in private, to engage in counterproductive behavior to guarantee their success (I.-S. Oh, Charlier, Mount, $\&$ Berry, 2014), to engage in information manipulation to cover up poor decisions (Caldwell \& O'Reilly, 1982), to have lower honesty-humility (Ashton \& Lee, 2005), and to have lower behavioral integrity (i.e., inconsistencies between promises and actions) (Simons, 2002). Thus, with respect to selfmonitoring and ethics, this study proposes: 
H3: The higher an individual's self-monitoring, the more likely he/she will have unethical intentions.

Social networking, by its nature, involves a process that typically requires an extended time frame for developing contacts, regardless of an individual's self-monitoring personality. Therefore, temporal perspective is another personal characteristic that can influence social capital development and, ultimately, ethical decision-making. Defined by Zimbardo and Boyd (1999, p. 1271) as "the often nonconscious process whereby the continual flow of personal and social experiences are assigned to temporal categories, or time frames, that help to give order, coherence, and meaning of those events", an individual's time perspective can manifest itself as a style or disposition influencing one's judgments, decisions, and actions.

Future time orientation, for example, is generally associated with an individual's preference for consistency and higher considerations of future consequences. With respect to social relationships, future-oriented actors often have a scarcity of social relations due to their focus on achieving high-level standards of work, with less time allotted to networking activities (Zimbardo \& Boyd, 1999). Consequently, they have been found to prefer building their networks with supportive significant others - close parents and friends (Holman \& Zimbardo, 2009).

The desire for consistency is something that future-oriented individuals share with low selfmonitors, as a close, dense network is necessary for internalizing a clear and consistent set of expectations and values (Coleman, 1990). Indeed, Oner (2002) found low self-monitors to have a high future time orientation in romantic relationships. A similar association between these personal characteristics might be expected in other contexts such as work settings, where low self-monitors are more willing than high self-monitors to invest the time necessary to develop close relationships (Gangestad \& Snyder, 2000). Therefore,

H4: The higher an individual's future orientation, the less likely he/she will exhibit brokerage (centrality) in his/her advice social network.

H5: The higher an individual's self-monitoring, the lower his/her future orientation.

The relationship of future orientation to unethical decision-making might best be understood through the lens of construal level theory. According to construal level theory (Trope \& Liberman, 2003), people interpret objects and events differently according to the temporal distance. The greater the temporal distance, the higher the abstraction and the more general view (seeing the forest rather than the trees). People with a closer perspective, on the other hand, have interpretations of specific details of an event that are more concrete, but have lower levels of understanding of the structure as a whole and therefore fail to integrate various aspects. Temporal distance affects analysis from the point of view of why (future) versus how (present).

Eyal, Sagristano, Trope, Liberman, and Chaiken (2009), based on construal level theory, found that people are more likely to use their values as a guide to behavioral intentions in the distant future than current behavior in the near future. Although individuals see their values as central to their selfidentity and use them to guide future planning of their actions, more situational aspects determine their actual behavior. They argued that this occurs "since perceptions of distant future situations highlight more abstract, high-level features than near future situations, they are more influenced by high-level constructs such as values" (p. 35). Eyal et al. (2009) suggested that individuals often view themselves in terms of "what is really important to me in life" (p. 42) only when they think of themselves in a distant abstract way. When they think of their actions from a proximal perspective, their true self may lose its clarity to pragmatic, situational constraint (money, time).

Therefore, individuals with a greater future orientation are likely to be concerned about the implications of an unethical act and, as a consequence, their immediate intentions might be inclined towards ethical decision-making. The lesser the future orientation of an individual, the more likely his/her unethical intentionality and behavior (since the future and its consequences are discounted). Existing empirical research seems to support this theory. According to Keough, Zimbardo, and Boyd 
(1999), future-oriented individuals are less likely to take health risks or engage in sensation seeking. In a related study, Zimbardo and Boyd (1999) found future orientation to be associated with greater conscientiousness (scrupulousness and perseverance) as well as a lower propensity for lying. Similarly, future orientation has been found to be related to higher levels of ethical values (Nevins, Bearden, \& Money, 2007), more ethical behavior (Hershfield et al., 2012), and organization citizenship behavior (Joireman, Daniels, Georfe-Falvy, \& Kamdar, 2006). Overall, this suggests the following relationship between future orientation and ethics:

H6: The lower an individual's future orientation, the more likely he/she will have unethical intentions.

\section{Methods}

\section{Participants and procedures}

The participants in this study consisted of 129 professionals: 6 (4.7\%) VPs or above, 27 (20.9\%) directors, $54(41.9 \%)$ managers, $18(14.0 \%)$ supervisors, and $24(18.6 \%)$ non-supervisors. The mean age was $43.1(\mathrm{SD}=8.9)$, the average tenure was 9.5 years $(\mathrm{SD}=7.7)$, and seventy $(54.3 \%)$ were males. The majority, 113 (87.6\%), were Brazilian, but all spoke English (the language of the surveys). The sample was based on convenience, with requests sent to business people from different organizations in one of the author's networks, and with snowball requesting to forward to other colleagues in their work network. To collect survey, a web-based data collection tool was employed. The survey consisted of multiple questionnaires focused on social networks, self-monitoring, future time perspective, and ethical intentions, and was constructed to prevent participants from inadvertently skipping questions.

\section{Measures}

\section{Ethical intentions}

To measure ethical intentions, two business scenarios were adapted from Glover, Bumpus, Logan, and Ciesla (1997). In each scenario participants are faced with a distinct ethical issue. In the first scenario (called Competitor), participants find themselves in the role of a newly appointed marketing manager. While attending the annual industry association meeting to get a clearer understanding of competitors' strategies, you discover that your main competitor's marketing manager, who has just left the elevator you are on, has dropped a copy of their marketing and sales plan. Would you look at the competitor's marketing plan before you returned it (definitely not, probably not, probably yes, definitely yes)?

In the second scenario (called Bribery), participants are working on a very important equipment sale. Working with your company's partner alliance, you discover that this partner, which is the key liaison with the customer, has committed a series of under-the-table payments to various people (intermediaries, buyer representatives) in order to secure the contract. You and your company, however, are not (and will not be) directly involved in those payments. Would you continue to work with this partner (definitely not, probably not, probably yes, definitely yes)?

These two scenarios were intentionally selected as their issues represent different levels of moral intensity (Jones, 1991). The Bribery scenario has a higher moral intensity than the Competitor scenario (Glover, Bumpus, Logan, \& Ciesla, 1997). According to Jones' (1991) Issue-Contingent Model, moral intensity (i.e., the extent of issue-related moral imperative in a situation) is a potential determinant of ethical decision-making. Kish-Gephart et al. (2010) suggested that the moral intensity construct should be formed by three factors: social consensus, proximity (affected/benefited), and expected harm (those related to harm to the victims: magnitude of consequences, concentration of effect, probability of effect and temporal immediacy). 


\section{Social network (constraint and betweenness centrality)}

Consistent with Burt (1992), this study used an egocentric social network survey to collect data about respondents' networks. Specifically, each respondent (referred to as ego) was asked to list the initials of up to five individuals who are important sources of professional advice (whom you approach when you have a work-related problem or you want advice on a decision you have to make) (Ibarra, 1992). As found by Merluzzi and Burt (2013), five names are considered to be the cost effective number to be requested, enough to reveal network effects. For each contact in the network (referred to as an alter), the respondent was asked for information about the strength of the connection (close, less close, weak) and this party's gender. In addition, respondents were required to indicate how strong a connection the alters have to each other: close, less close, weak, or avoid. Although the data are perceived rather than actual networks, we followed other scholars who argued that rates of reciprocation were found to be sufficiently high to show the measures reflect more than ego's perception (e.g., Ma, Huang, \& Shenkar, 2011).

Further, we employed two different measures of social network structure to measure how central an individual is in his/her network: betweenness centrality (Freeman, 1979) - the extent to which an ego lies on the shortest paths between alters - and constraint (Burt, 1992) - network concentrated on contacts among all its members (low constraint means larger numbers of structural holes, i.e. low brokerage). Individuals in low betweenness centrality (or high constraint) are the ones who are located in more closed ego-networks. These two variables are in line with the social network theories that drove most of the theoretical background of the study and are correlated. They were calculated using Ucinet software (Borgatti, Everett, \& Freeman, 2002); ego-alter and alter-alter relationships were dichotomized: close=1, and less close/weak/avoid $=0$.

\section{Self-monitoring}

This study used the 25-item self-monitoring instrument employed by Snyder (1987) in the continuous format, instead of the shorter 18-item version (Gangestad \& Snyder, 2000), as the metaanalysis of Day, Schleicher, Unckless and Hiller (2002) showed that the former is more reliable than the latter. For each statement, participants were asked to respond using a 5-point Likert scale, from strongly disagree to strongly agree. The Cronbach alpha for this instrument was .77, in line with other studies (e.g., Day et al., 2002), and above the generally accepted .70 level. Self-monitoring was used in its continuous form in the main analyses (CFA and SEM), but we also introduced a dichotomized selfmonitoring in the text to offer additional analyses.

\section{Future time perspective}

Future orientation was measured using a 12-item, 5-point Likert scale (from strongly disagree to strongly agree), taken from the future sub-scale of the Zimbardo Time Perspective Inventory short version (Keough, Zimbardo, \& Boyd, 1999). This scale was preferred over later versions because it includes time pressure items (items 9 and 10), and had a Cronbach alpha of .72 (after deleting item 8).

\section{Analyses}

Confirmatory factor analysis (CFA) and structural equation modeling (SEM) were used to analyze the proposed model of individual factors, social networks, and unethical intentions (H1-H6). As prior research has found that gender and age can influence ethicality (O'Fallon \& Butterfield, 2005), and that females have lower centrality (higher constraint) than do males (Burt, 1998; Ibarra, 1997), these variables also were included in this analysis. The CFA model included the same constructs and variables as in the SEM model: individual factors (self-monitoring as a continuous score, future, gender, and age), social network (centrality and constraint) and unethical intentions (competitor and bribery scenarios). 


\section{Results}

The descriptive statistics and correlations for the primary variables in the model are shown in Table 1. For self-monitoring, the mean was $2.81(\mathrm{SD}=0.42)$. Consistent with past research (Bolino \& Turnley, 2003), the median (2.80) was used to classify the respondents as high or low self-monitors in order to develop additional analyses. The sample was composed of 69 high self-monitors and 60 low self-monitors. Usually populations present more low self-monitors, however the breakdown of self-monitors by hierarchical level in this sample is in line with that reported by Day and Schleicher (2006), as there is a greater tendency for high self-monitors at the top of organizations. In terms of gender, $54.28 \%$ of the males and $51.66 \%$ of the females were high self-monitors. Self-monitoring was negatively correlated with age $(\mathrm{r}=-.31, \mathrm{p}<.001)$. For future orientation, the range was from 5.60 to 11.60 , with a mean of $8.81(\mathrm{SD}=1.13)$. As shown in Table 1, there were significant correlations between future orientation and gender $(\mathrm{r}=.23, \mathrm{p}<.01$; male $=0$, female $=1)$ as well as between future orientation and age $(\mathrm{r}=.19, \mathrm{p}<.05)$. For social networks, constraint varied from zero to 1.13 (mean=0.65, $\mathrm{SD}=0.27$ ), while betweenness centrality varied from zero to 2.94 (mean=1.19, $\mathrm{SD}=0.95)$ ( $\mathrm{LN}$ transformation).

Table 1

\section{Descriptive Statistics and Correlation Matrix for Primary Variables ${ }^{\mathrm{a}}$}

\begin{tabular}{lccccccccc}
\hline Variable & Mean & SD & 1 & 2 & 3 & 4 & 5 & 6 & 7 \\
\hline Individual Factors & & & & & & & & & \\
1. Gender ${ }^{\mathrm{b}}$ & .46 & .50 & & & & & & & \\
2. Age & 43.11 & 8.92 & .02 & & & & & & \\
3. Self-monitoring & 2.81 & 0.42 & -.05 & $-.31^{* * *}$ & & & & & \\
4. Future orientation & 8.81 & 1.13 & $.23^{* *}$ & $.19^{*}$ & $-.18^{*}$ & & & & \\
Social Network & & & & & & & & & \\
5. Constraint & .65 & .27 & $.16^{\dagger}$ & .04 & -.14 & .01 & & & \\
6. Centrality & 1.19 & .95 & $-.19^{*}$ & -.13 & .14 & .01 & $-.76^{* * *}$ & & \\
Unethical Intentions & & & & & & & & & \\
(Scenarios) & & & & & & & & & \\
7. Competitor & 2.41 & 1.04 & -.08 & $-.23^{* *}$ & $.18^{*}$ & -.13 & .12 & -.12 & \\
8. Bribery & 1.70 & .78 & -.10 & -.06 & $.28^{* * *}$ & -.06 & .03 & -.03 & $.23^{* *}$ \\
\hline
\end{tabular}

Note. ${ }^{\mathrm{a}} \mathrm{N}=129,{ }^{\mathrm{b}}$ Male $=0$, Female $=1$.

${ }^{\dagger} \mathrm{p}<.10,{ }^{*} \mathrm{p}<.05,{ }^{* *} \mathrm{p}<.01,{ }^{* * *} \mathrm{p}<.001$.

The mean values for the two scenarios (competitor: $2.41, \mathrm{SD}=1.04$; bribery: $1.70, \mathrm{SD}=0.78$ ) reflect different levels of associated morality. Nonetheless, there was a significant correlation between the scenarios as regards participants' unethical intentionality $(\mathrm{r}=.23, \mathrm{p}<.01)$. In addition, self-monitoring correlated significantly and positively with intentionality preferences for both scenarios: competitor $(\mathrm{r}=.18, \mathrm{p}<.05)$ and bribery $(\mathrm{r}=.28, \mathrm{p}<.001)$. Social network variables did not correlate significantly with unethical intention.

Maximum likelihood was the estimation method used for both the measurement model (CFA) and the structural equation model (SEM). The CFA model fit the data well, as minimum was achieved: $\chi^{2}=20.86$; normalized $\chi^{2}=1.22$; RMSEA $=0.04$, p-close $=0.60 ; \mathrm{CFI}=0.98 ; \mathrm{GFI}=0.96$; no standardized residuals greater than $|2.5|$; and no modification indices. All factors were statistically significant and all loadings were equal to or greater than .50 , except for gender $(-.22, \mathrm{p}<.10)$, future orientation $(-.32$, $\mathrm{p}<.05)$, and the bribery scenario (.43, $\mathrm{p}<.05)$. Although two individual variables - gender and future orientation - could be candidates for deletion, this study followed Hair, Black, Babin and Anderson's (2010, p. 654) contention that "pursuit of a better fit at the expense of testing a true model is not a good 
trade-off" (i.e., optimally, one should approximate the theory to be tested rather than increase model fit). Moreover, it is important to keep gender in the model as males and females present quite different social network structures and networking behavior in general (Brink \& Benschop, 2014).

The structural equation model also fit the data well, with minimum achieved: $\chi^{2}=20.86$ (same as CFA); normalized $\chi^{2}=1.22$; RMSEA $=0.04$, $\mathrm{p}$-close $=0.60$; $\mathrm{CFI}=0.98$ and $\mathrm{GFI}=0.96$; no standardized residuals were greater than $|2.5|$. Olsson, Foss, Troye and Howell (2000) explained that nonnormality of data can affect significance tests because standard errors can be underestimated. Hair et al. (2010) suggested that MLE (maximum likelihood estimation) "has proven fairly robust to violations of the normality assumptions" (p. 645) and "that compared MLE with other techniques it produced reliable results in many circumstances" (p. 645). Moreover, Savalei (2008) found that MLE Chi-Square can be considered robust to non-normality only if there is a low level of missing data, which is the case of this study. We also tested the model using GLS estimation and it provided very similar parameter specifications and model fit $\left(\chi^{2}=22.46 ; \mathrm{GF}=0.96 ; \mathrm{CFI}=0.93 ; \mathrm{RMSEA}=0.04\right.$, pclose $\left.=0.51\right)$. Therefore, it is an additional indication that the correct structure is identified and the parameter estimations are accurate (Olsson, Foss, Troye, \& Howell, 2000). Figure 1 shows the structural model with the factor loadings (standardized regression weights).

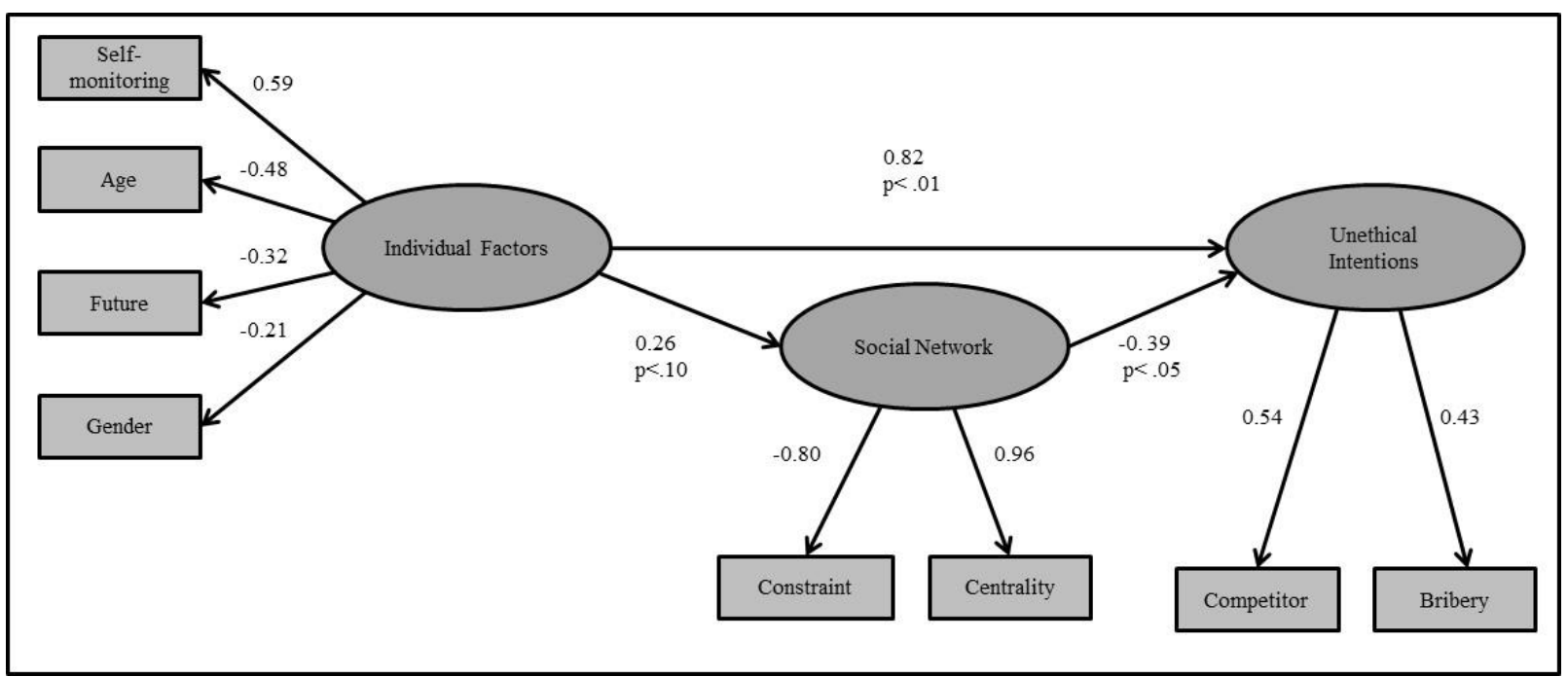

Figure 1. Structural Equation Model for Individual Factors, Social Network, and Unethical Intentions

Hypothesis 1, that the higher an individual's centrality, the more likely he/she will have unethical intentions, was not supported. In fact, in the congeneric model proposed, centrality is an indicator variable of the social network construct with a computed load of +0.96 . Since social network is negatively related to unethical intentions $(-0.39 ; \mathrm{p}<.05)$, it follows that centrality is negatively related to unethical intentions, not supporting H1. That is, the lower the centrality (higher constraint), the greater the unethical intentions.

The hypotheses that relate individual factors to unethical intentions were supported since the individual factors construct is positively related to the unethical intentions construct $(0.82 ; \mathrm{p}<.01)$, and self-monitoring and future orientation - which are indicator variables of the individual factors construct - had a positive computed load of +0.59 and a negative computed load of -0.32 , respectively. Therefore, the higher the self-monitoring, the greater the unethical intention (supporting H3), and the lower the future orientation, the greater the unethical intention (supporting H6). Further, H5 was also supported: the lower the future orientation, the higher the self-monitoring. The hypotheses that relate individual factors to social networking were marginally supported. Centrality has a positive computed load of +0.96 on this construct. Therefore, self-monitoring is marginally positively related to centrality $(\mathrm{H} 2)$ and future orientation is marginally negatively related to centrality (H4).

At first glance, the results might seem contradictory because self-monitoring is positively related to network centrality and is also positively related to unethical intentions. But the model made clear that 
it is a lack of centrality (high constraint) which is related to unethical intentions. The same type of contradiction is apparent when gender is considered: being female decreases unethical intentions (as it has a negative loading score), but also decreases centrality (increases constraint), which increases unethical intentions.

To clarify this contradiction it is necessary to disentangle the influence of individual factors, such as gender, on the creation of social networking structures. Similar to previous studies, males presented a higher centrality than did females (males=4.73, $\mathrm{SD}=4.90$; females $=3.20, \mathrm{SD}=4.21 ; \mathrm{F}=4.79, \mathrm{p}<.05$, $\eta^{2}=0.04$ ). Dichotomizing the self-monitoring variable, we found that self-monitor females had the lowest network centrality $(0.77, \mathrm{SD}=0.93)$, whereas high self-monitor females presented a significantly different centrality $(1.24, \mathrm{SD}=0.90)$, ANOVA $\left(\mathrm{F}=3.84, \mathrm{p}<.05, \eta^{2}=0.08\right)$. There was no significant difference in the network centrality between low self-monitor males $(1.29, \mathrm{SD}=0.87)$ and high selfmonitor males $(1.43, \mathrm{SD}=0.99)$.

On closer examination, high self-monitors in lower centrality were positively associated with unethical intentions, but ethical low self-monitor females also presented very low centrality. In this study, high self-monitors in lower centrality (higher constraint) are inclined towards unethical intentions. And males have higher self-monitoring scores. In fact, there was a decrease of network centrality when comparing unethical males (that is, for those who chose unethical competitor or bribery options) to ethical males, but even more so for the higher intensity moral case (bribery scenario): low self-monitor males - ethical $(1.40, \mathrm{SD}=0.83, \mathrm{n}=17)$ [competitor $(1.13, \mathrm{SD}=0.94, \mathrm{n}=14)$, bribery $(0.23$, $\mathrm{SD}=0.40, \mathrm{n}=3)$ ]; high self-monitor males - ethical $(1.87, \mathrm{SD}=0.90, \mathrm{n}=12)$ [competitor $(1.24, \mathrm{SD}=1.00$, $\mathrm{n}=25)$, bribery $(0.99, \mathrm{SD}=0.78, \mathrm{n}=13)]$.

\section{Discussion}

The objective of this study was to analyze the mutual interplay of individual factors and social situations in the choice of unethical intentions, focusing specifically on social networks and two individual factors - self-monitoring and temporal orientation. The findings provide evidence of the dynamics between individual factors and the creation of social networks, as well as insights into how these connections pose higher risks for unethical decision-making.

Self-monitoring was found to be a significant factor in predicting unethical intentions. Low selfmonitors were more ethical than high self-monitors in the two intentions-based scenarios. In the scenario involving a higher moral issue, which included the use of bribery by a partner, the difference was more pronounced. The second individual variable in this study, future orientation, provided weaker evidence of unethical intentions than did self-monitoring, probably as a function of the goal-orientated aspect of the measure used. Further, these two factors were interconnected, as future orientation was found to be negatively related to self-monitoring. A third individual variable, gender, was not found to be related to ethical intentions. It had weak significance compared to the other variables in the scenarios.

This study found that individuals in lower centrality increase the risk of unethical intentions. One explanation comes from Brass, Butterfield and Skaggs (1998), who have hypothesized that more centrally-located individuals have lower risk of unethical acts due to the increased chance of damaging their reputations. We argue that another explanation stems from the need for high control to reduce risk and ensure the success of the unethical event, which only a closed network (the network in which the individual has no or very low centrality) can provide, such as the "honor among the thieves" (Brass et al., 1998, p. 18). However, ethical low self-monitor women also were found to be in very closed networks, so social networks alone do not explain ethical decision-making.

Considering the controversy regarding who more closely adheres to social norms, high or low self-monitors, the problem may be in the definition of the focal group that defines such norms. If by social norms an ethical environment is assumed, then the evidence shows that low self-monitors adhere 
more closely to the norms. The results suggest that many respondents follow a business social norm based on the ethics of the battlefield.

\section{Theoretical contributions}

This research represents a step forward in understanding the adoption of multiple and simultaneous factors on ethical decision-making. By extending the recent literature on social capital's dark side and following the claims for more research on how individual differences contribute to social network development (Kilduff \& Krackhardt, 2008), this study has made three contributions to social capital and ethical decision-making research.

First, this research helped to clarify a contradiction in social network research and ethics. Previous studies suggest that people in high centrality in their networks may suffer from a false consensus bias a false moral approval or approbation from others - that could lead to a higher risk of unethical acts (Flynn \& Wiltermuth, 2010; Jones, 1991). This study found that the highest rate of unethical acts came from high self-monitors (who usually have high centrality in their networks), but the risk of unethical acts actually increases for those individuals in low centrality, regardless of an issue's moral intensity.

Second, while often studied as a main effect with respect to morality and ethics, gender has generally been overlooked as a moderator of network development and ethical decision-making. Gender and self-monitoring were found to affect the pattern of social networks in different ways, and the evidence collected in this study suggests that these two dimensions interact, affecting women more prominently than men. Moreover, the results of our study show that the structure of the social network is not enough to predict results and, as Brass et al. (1998) suggested, social networks represent only one factor/perspective among others. Therefore, it is necessary to consider the individual who is in the network (Kilduff \& Krackhardt, 2008).

Finally, while adding to our understanding of the role of high self-monitors in the organizational decision-making process (including their relation to a lower future orientation, as well as their interaction with gender), this paper also introduced the potential benefits of low self-monitors in the management of organizational behavior. This contribution addresses Mehra, Kilduff and Brass's (2001) claim that a focus on low self-monitors has been largely absent from the literature, as most research has discussed the contributions and outcomes of high self-monitors.

\section{Practical implications}

Identifying causes and ways to prevent unethical behavior and corruption in business and society in general is an endeavor that should drive business. Management should be cautious about the assumed advantages of high self-monitor personalities and the characteristics of social networks that could produce an endemic lack of ethical decision-making. Career evaluations should be related not only to what was achieved but to how it was achieved (including the guarantee of ethical means), and management should be aware of strong impression management (including misrepresentations) by high self-monitors. Additionally, it is necessary to recognize the contributions of low self-monitors vis-à-vis their ability to be committed to the company's best interests, making decisions that above all do not compromise ethics.

\section{Limitations and future research}

As with all research, the findings from this study come with some caveats. First, the future orientation measure proved to have low variance for our sample. Future perspective, although related to some degree to both social network and unethical options, did not enable a disentangling of its various dimensions (e.g., time pressure and goal-orientation) from the outcomes. We suggest that other dimensions of the time-perspective scale (e.g., present) should be considered in future research. 
Second, information about the ethical decision-making of alters (network contacts) was beyond the scope of this study, which therefore missed a more compelling view of the notion that "birds of a feather flock together" (McPherson, Smith-Lovin, \& Cook, 2001, p. 417). That is, it was not possible to verify the similarity of ethical values among those in the advice network of the respondents. To undertake such investigation, future research might employ other methods for collecting social network data in which respondents point openly to the name of each alter, and then the same questions about ethical decision-making would be collected from the alters. However, this method raises privacy issues, which are even more challenging considering the sensitivity of ethical questions.

Third, this research focused on the individual level, although ethical behavior can also be influenced by country or corporate ethical culture. Brazilians comprised the majority of the participants in the current study, but there was some evidence that unethical intentions may be the result of globalization of the way to do business, because respondents of other nationalities also chose unethical options. Therefore, future studies could replicate this study in other countries. An important line of research could be to develop a multi-level analysis. As some scholars have suggested, social capital is contingent on culture (e.g., Xiao \& Tsui, 2007), and culture or economic and social levels have an influence on the dark side of social capital (Martin et al., 2007). Another variable in this study - future orientation - is also associated with cultural values.

Finally, the design of the internet-based survey which forced the respondents to answer all the questions (and therefore avoiding missing data) could have affected both drop-out rates and the quality of answers. Therefore, future research could implement other alternatives, such as a soft reminder option. This could reduce the possibility of response oversights while still allowing respondents to not respond if they don't know or are not comfortable answering (Décieux, Mergener, Neufang, \& Sischka, 2015; Dillman, Smyth, \& Christian, 2014).

\section{Final Comments}

In an increasingly interconnected and interdependent world, fraud and corruption are among the most serious problems facing organizations and nations. To better address their emergence and growth, it is important to understand the influence of significant individual and situational factors on moral reasoning. Social networks lie at the center of this challenge. As unethical attitudes/behavior appear to have a symbiotic relationship with social structures and their influences, the effects of individual factors such as self-monitoring and future orientation on social network development remain critical areas of investigation.

\section{References}

Adler, P. S., \& Kwon, S. (2002). Social capital: prospects for a new concept. Academy of Management Review, 27(1), 17-40. http://dx.doi.org/10.5465/AMR.2002.5922314

Ajzen, I. (1991). The theory of planned behavior. Organizational Behavior and Human Decision Process, 50(2), 179-211. http://dx.doi.org/10.1016/0749-5978(91)90020-T

Ajzen, I., \& Fishbein, M. (1980). Understanding attitudes and predicting social behavior. Englewood Cliffs, NJ: Prentice-Hall.

Ashton, M. C., \& Lee, K. (2005). Honesty-humility, the Big-Five, and the five-factor model. Journal of Personality, 73(5), 1321-1353. http://dx.doi.org/10.1111/j.1467-6494.2005.00351.x 
Ayios, A., Jeurissen, R., Manning, P., \& Spence, L. J. (2014). Social capital: a review from an ethics perspective. Business Ethics: A European Review, 23(1), 108-124. http://dx.doi.org/10.1111/beer.12040

Bizzi, L. (2013).The dark side of structure holes: a multilevel investigation. Journal of Management, 39(6), 1554-1578. http://dx.doi.org/10.1177/0149206312471385

Bolino, M. C., Klotz, A. C., Turnley, W. H., \& Harvey, J. (2013). Exploring the dark side of organizational citizenship behavior. Journal of Organizational Behavior, 34(4), 542-559. http://dx.doi.org/10.1002/job.1847

Bolino, M. C., \& Turnley, W. H. (2003). More than one way to make impression: exploring profiles of impression management. Journal of Management, 29(2), 141-160. http://dx.doi.org/10.1177/014920630302900202

Borgatti, S. P., Everett, M. G., \& Freeman, L. C. (2002). Ucinet for Windows: software for social network analysis. Harvard, MA: Analytic Technologies.

Brass, D. J., Butterfield, K. D., \& Skaggs, B. C. (1998). Relationships and unethical behavior: a social network perspective. Academy of Management Review, 23(1), 14-31. http://dx.doi.org/10.2307/259097

Brink, M., van den, \& Benschop, Y. (2014). Gender in academic networking: the role of gatekeepers in professional recruitment. Journal of Management Studies, 51(3), 460-492. http://dx.doi.org/10.1111/joms.12060

Burt, R. S. (1992). Structural holes: the social structure of competition. Cambridge, MA: Harvard University Press.

Burt, R. S. (1998). The gender of social capital. Rationality and Society, 10(1), 5-46. http://dx.doi.org/10.1177/104346398010001001

Caldwell, D. F., \& O'Reilly, C. A., III. (1982). Responses to failure: the effects of choice and responsibility on impression management. Academy of Management Journal, 25(1), 121-136. http://dx.doi.org/10.2307/256028

Coleman, J. S. (1990). Foundations of social theory. Cambridge: MA: Harvard University Press.

Collins, J. D., Uhlenbruck, K., \& Rodriguez, K. (2009). Why firms engage in corruption: a top management perspective. Journal of Business Ethics, 87(1), 89-108. http://dx.doi.org/10.1007/s10551-008-9872-3

Craft, J. L. (2013). A review of empirical ethical decision-making literature: 2004-2011. Journal of Business Ethics, 117(2), 221-259. http://dx.doi.org/10.1007/s10551-012-1518-9

Day, D. V., \& Schleicher, D. J. (2006). A motive based perspective. Journal of Personality, 74(3), 685714. http://dx.doi.org/10.1111/j.1467-6494.2006.00389.x

Day, D. V., Schleicher, D. J., Unckless, A. L., \& Hiller, N. J. (2002). Self-monitoring personality at work: a meta-analytic investigation of construct validity. Journal of Applied Psychology, 87(2), 390-401. http://dx.doi.org/10.1037//0021-9010.87.2.390

Décieux, J. P., Mergener, A., Neufang. K. M., \& Sischka, P. (2015). Implementation of the forced answering option within online surveys: do higher item response rates come at the expense of participation and answer quality? Psihologija, 48(4), 311-326. http://dx.doi.org/10.2298/PSI1504311D 
Dillman, D. A., Smyth, J. D., \& Christian, L. M. (2014). Internet, phone, mail, and mixedmode surveys: the tailored design method. New Jersey: John Wiley \& Sons.

Dougherty, T. W., Cheung, Y. H., \& Florea, L. (2008). The role of personality in employee developmental networks. Journal of Managerial Psychology, 23(6), 653-669. http://dx.doi.org/10.1108/02683940810894738

Eyal, T., Sagristano, M. D., Trope, Y., Liberman, N., \& Chaiken, S. (2009). When values matter: expressing values in behavioral intentions for the near versus distant future. Journal of Experimental Social Psychology, 45(1), 35-43. http://dx.doi.org/10.1016/j.jesp.2008.07.023

Flynn, F. J., \& Wiltermuth, S. S. (2010). Who's with me? False consensus, brokerage and ethical decision making in organizations. Academy of Management Journal, 53(5), 1074-1089. http://dx.doi.org/10.5465/AMJ.2010.54533202

Ford, R. C., \& Richardson, W. D. (1994). Ethical decision making: a review of the empirical literature. Journal of Business Ethics, 13(3), 205-221. http://dx.doi.org/10.1007/BF02074820

Freeman, L. C. (1979). Centrality in social networks clarification. Social Networks, 1(3), 215-239. http://dx.doi.org/10.1016/0378-8733(78)90021-7

Gangestad, S. W., \& Snyder, M. (2000). Self-monitoring: appraisal and reappraisal. Psychological Bulletin, 126(4), 530-555. http://dx.doi.org/10.1037/0033-2909.126.4.530

Garrett, B. L. (2014). Too big to jail: how prosecutors compromise with corporations. Cambridge, MA: Belknap/Harvard Business Press.

Glover, S. H., Bumpus, M. A., Logan, J. E., \& Ciesla, J. R. (1997). Re-examining the influence of individual values on ethical decision making. Journal of Business Ethics, 16(12), 1319-1329. http://dx.doi.org/10.1023/A:1005758402861

Gunia, B. C., Wang, L., Huang, L., Wang, J., \& Murnighan, J. K. (2012). Contemplation and conversation: subtle influences on moral decision making. Academy of Management Journal, 55(1), 13-33. http://dx.doi.org/10.5465/amj.2009.0873

Hair, J. F., Black, W. C., Babin, B. J., \& Anderson, R. E. (2010). Multivariate data analysis. New Jersey: Prentice Hall Inc.

Hershfield, H. E., Cohen, T. R., \& Thompson, L. (2012). Short horizon and tempting situations: lack of continuity to our future selves leads to unethical decision making and behavior. Organizational Behavior and Human Decision Process, 117, 298-310. http://dx.doi.org/10.1016/j.obhdp.2011.11.002

Hewlin, P. F. (2003). And the award for the best actor goes to...: facades of conformity in organizational settings. Academy of Management Review, 28(4), 633-642. http://dx.doi.org/10.5465/AMR.2003.10899442

Hogue, M., Levashina, J., \& Hang, H. (2013). Will I fake it? The interplay of gender, machiavellianism, and self-monitoring on strategies for honesty in job interviews. Journal of Business Ethics, 117(2), 399-411. http://dx.doi.org/10.1007/s10551-012-1525-x

Holman, E. A., \& Zimbardo, P. G. (2009). The social language of time: the time perspective-social network connection. Basic and Applied Social Psychology, 31(2), 136-147. http://dx.doi.org/10.1080/01973530902880415

Ibarra, H. (1992). Homophily and differential returns: sex differences in network structures and access in an advertising firm. Administrative Science Quarterly, 37(3), 422-447. http://dx.doi.org/10.2307/2393451 
Ibarra, H. (1997). Paving an alternative route: gender differences in managerial networks. Social Psychology Quarterly, 60(1), 91-102. http://dx.doi.org/10.2307/2787014

Ibarra, H., Kilduff, M., \& Tsai, W. (2005). Zooming in and out: connecting individuals and collectivities at the frontiers of organizational. Organization Science, 16(4), 359-371. http://dx.doi.org/10.1287/orsc.1050.0129

Janicki, G. A., \& Larrick, R. P. (2005). Social network schemas and the learning of incomplete network. Journal of Personality and Social Psychology, 88(2), 348-364. http://dx.doi.org/10.1037/00223514.88.2.348

Joireman, J., Daniels, D., Georgy-Falvy, J., \& Kamdar, D. (2006). Organization citizenship behaviors as a function of empathy, CFC and employee time horizon: an initial exploration using in basket simulation of OCB's. Journal of Applied Psychology, 36(9), 2266-2292. http://dx.doi.org/10.1111/j.0021-9029.2006.00103.x

Jones, T. M. (1991). Ethical decision-making by individuals in organizations: an issue-contingent model. Academy of Management Review, 16(2), 366-395. http://dx.doi.org/10.2307/258867

Jones, T. M., \& Ryan, L. V. (1997). The link between ethical judgment and action in organizations: a moral approbation approach. Organization Science, 8(6), 663-680. http://dx.doi.org/10.1287/orsc.8.6.663

Kalish, Y., \& Robins, G. (2006). Psychological predispositions and network structure: the relationship between individual predispositions, structure hole and network closure. Social Networks, 28(1), 56-84. http://dx.doi.org/10.1016/j.socnet.2005.04.004

Keough, K. A., Zimbardo, P. G., \& Boyd, J. N. (1999). Who is smoking, drinking and using drugs: time perspective as a predictor of substance use. Basic and Applied Social Psychology, 21(2), 149-164. http://dx.doi.org/10.1207/15324839951036498

Kilduff, M. (1992). The friendship network as a decision-making resource: dispositional moderators of social influences on organizational choice. Journal of Personality and Social Psychology, 62(1), 168-180. http://dx.doi.org/10.1037/0022-3514.62.1.168

Kilduff, M., \& Krackhardt, D. (2008). Interpersonal networks in organizations. Cognition, personality, dynamics and culture. New York: Cambridge University Press.

Kish-Gephart, J. J., Harrison, D. A., \& Treviño, L. K. (2010). Bad apples, bad cases, bad barrels: metaanalytic evidence about sources of unethical decision at work. Journal of Applied Psychology, 95(1), 1-31. http://dx.doi.org/10.1037/a0017103

Lee, S. H. M. (2013). Ethics and expertise: a social networks perspective. Journal of Business Ethics, 118(3), 607-621. http://dx.doi.org/10.1007/s10551-012-1609-7

Lin, N. (2001). A theory of social structure and action. New York: Cambridge University Press.

Loe, T. W., Ferrel, L., \& Mansfield, P. (2000). A review of empirical studies assessing ethical decision making in business. Journal of Business Ethics, 25(3), 185-204. http://dx.doi.org/10.1023/A:1006083612239

Ma, R., Huang, Y. C., \& Shenkar, O. (2011). Social networks and opportunity recognition: a cultural comparison between Taiwan and the United States. Strategic Management Journal, 32(11), 11831205. http://dx.doi.org/10.1002/smj.933

Martin, K. D., Cullen, J. B., Johnson, J. L., \& Parboteeah, K. P. (2007). Deciding to bribe: a cross-level analysis of firm and home country influences on bribery activity. Academy of Management Journal, 50(6), 1401-1422. http://dx.doi.org/10.5465/AMJ.2007.28179462 
McPherson, M., Smith-Lovin, L., \& Cook, J. M. (2001). Birds of a feather: homophily in social networks. Annual Review Sociology, 27, 415-444. http://dx.doi.org/10.1146/annurev.soc.27.1.415

Mehra, A., Kilduff, M., \& Brass, D. J. (2001). The social network of high and low self-monitors: implications for workplace performance. Administrative Science Quarterly, 46(1), 121-146. http://dx.doi.org/10.2307/2667127

Merluzzi, J., \& Burt, R. S. (2013). How many names are enough? Identifying network effects with the least set of listed contacts. Social Networks, 35(3), 331-337. http://dx.doi.org/10.1016/j.socnet.2013.03.004

Nevins, J. L., Bearden, W. O., \& Money, B. (2007). Ethical values and long-term orientation. Journal of Business Ethics, 71(3), 261-274. http://dx.doi.org/10.1007/s10551-006-9138-x

Nielsen, R. P. (2003). Corruption networks and implications for ethical corruption reform. Journal of Business Ethics, 42(2), 125-149. http://dx.doi.org/10.1023/A:1021969204875

O'Fallon, M. J., \& Butterfield, K. D. (2005). A review of the empirical ethical decision-making literature: 1996-2003. Journal of Business Ethics, 59(4), 375-413. http://dx.doi.org/10.1007/s10551-005-2929-7

Oh, H., \& Kilduff, M. (2008). The ripple effect of personality on social structure: self-monitoring origins of network brokerage. Journal of Applied Psychology, 93(5), 1155-1164. http://dx.doi.org/10.1037/0021-9010.93.5.1155

Oh, I.-S., Charlier, S. D., Mount, M. K., \& Berry, C. M. (2014). The two faces of high self-monitoring: chameleonic moderating effects of self-monitoring on the relationship between personality traits and counter-productive work behavior. Journal of Organization Behavior, 35(1), 92-111. http://dx.doi.org/10.1002/job.1856

Olsson, U. H., Foss, T., Troye, S. V., \& Howell, R. D. (2000). The performance of ML, GLS and WLS estimation in Structural Equation Modeling under conditions of misspecification and $\begin{array}{llll}\text { nonnormality. Structural } & \text { Equations }\end{array}$ http://dx.doi.org/10.1207/S15328007SEM0704_3

Oner, B. (2002). Self-monitoring and future time orientation in romantic relationships. The Journal of Psychology, 136(4), 420-424. http://dx.doi.org/10.1080/00223980209604168

Payne, G. T., Moore, C. B., Griffis, S. E., \& Autry, C. W. (2011). Multilevel challenges and opportunities in social capital research. Journal of Management, 37(2), 491-520. http://dx.doi.org/10.1177/0149206310372413

Pinto, J., Leana, C. R., \& Pil, F. K. (2008). Corrupt organizations or organizations of corrupt individuals? Two types of organization-level corruption. Academy of Management Review, 33(3), 685-709. http://dx.doi.org/10.5465/AMR.2008.32465726

Rest, J. R. (1986). Moral development: advances in research and theory. New York: Praeger.

Sasovova, Z., Mehra, A., Borgatti, S. P., \& Schippers, M. C. (2010). Network churn: the effects of selfmonitoring personality on brokerage dynamics. Administrative Science Quarterly, 55(4), 639670. http://dx.doi.org/10.2189/asqu.2010.55.4.639

Savalei, V. (2008). Is the ML Chi-Square ever robust to nonnormality? A cautionary note with missing data. Structural Equation Modeling, 15(1), 1-22. http://dx.doi.org/10.1080/10705510701758091 
Shah, P. P. (1998). Who are employees' social referents? Using a network perspective to determine referents others. Academy of Management Journal, 41(3), 249-268. http://dx.doi.org/10.2307/256906

Simons, T. (2002). Behavioral integrity: the perceived alignment between managers' words and deeds as a research focus. Organization Science, 13(1), 18-35. http://dx.doi.org/10.1287/orsc.13.1.18.543

Snyder, M. (1987). Public appearances, private realities: the psychology of self-monitoring. New York: Freeman.

Snyder, M., Gangestad, S., \& Simpson, J. A. (1983). Choosing friends as activity partners: the role of self-monitoring. Journal of Personality and Social Psychology, 45(5), 1061-1072. http://dx.doi.org/10.1037/0022-3514.45.5.1061.

Snyder, M., \& Kendzierski, D. (1982). Choosing social situations: investigating the origins of correspondence between attitudes and behaviors. Journal of Personality, 50(3), 280-295. http://dx.doi.org/10.1111/j.1467-6494.1982.tb00751.x

Snyder, M., \& Simpson, J. A. (1984). Self-monitoring and dating relationships. Journal of Personality and Social Psychology, 47(6), 1281-1291. http://dx.doi.org/10.1037/0022-3514.47.6.1281

Trevino, L. K. (1986). Ethical decision-making in organizations: a person-situation interactionist model. Academy of Management Review, 11(3), 601-617. http://dx.doi.org/10.5465/AMR.1986.4306235

Trope, Y., \& Liberman, N. (2003). Temporal construal. Psychological Review, 110(3), 403-421. http://dx.doi.org/10.1037/0033-295X.110.3.403

Xiao, Z., \& Tsui, A. S. (2007). When brokers may not work: the cultural contingency of social capital in Chinese high-tech firms. Administrative Science Quarterly, 52(1), 1-31. http://dx.doi.org/10.2189/asqu.52.1.1

Zimbardo, P. G., \& Boyd, J. N. (1999). Putting time into perspective: a valid, reliable individual differences metric. Journal of Personality and Social Psychology, 77(6), 1271-1288. http://dx.doi.org/10.1037/0022-3514.77.6.1271

\title{
Authors' Profiles
}

\author{
Ana Carla Bon \\ Rua Marques de São Vicente, 225, Gávea, 22431-040, Rio de Janeiro, RJ, Brazil. E-mail address: anacarla.bon@hotmail.com \\ Roger James Volkema \\ Rua Marques de São Vicente, 225, Gávea, 22431-040, Rio de Janeiro, RJ, Brazil. E-mail address: volkema@ american.edu \\ Jorge Ferreira da Silva \\ Rua Marques de São Vicente, 225, Gávea, 22431-040, Rio de Janeiro, RJ, Brazil. E-mail address: shopshop@ iag.puc-rio.br
}

